\title{
ASSESSMENT OF ANTIOXIDANT AND ANTIBACTERIAL ACTIVITIES OF CYSTOSEIRA MEDITERRANEA AND PADINA PAVONICA FROM ALGERIAN NORTH-EAST FOR A POTENTIAL USE AS A FOOD PRESERVATIVE
}

\author{
B. Keramane*, N. Touati , K. Saidani, A. Taguelmimt, I. Zair, and F. Bedjou \\ Laboratoire de Biotechnologies Végétales et Ethnobotanique, Faculté des Sciences de la Nature et de la Vie, \\ Université de Bejaia, 06000 Bejaia. Algeria. \\ (Received: 9 May 2020; accepted: 27 June 2020)
}

\begin{abstract}
The aim of this work was to evaluate the antioxidant and antibacterial activities of two marine algae, Cystoseira mediterranea and Padina pavonica, extracts. Total phenols (TPC), carotenoids, and phlorotannins contents of the extracts obtained by four extraction solvents were determined and compared. The highest TPC content was observed for aqueous extract of $C$. mediterranea with $37.09 \pm 0.46 \mathrm{mg} \mathrm{GAE} / \mathrm{g}$ DE followed by ethanol extract of $P$. pavonica (24.28 $\pm 0.99 \mathrm{mg} \mathrm{GAE} / \mathrm{g} \mathrm{DE})$, which showed the highest phlorotannins content $(1.18 \pm 0.18 \mathrm{mg} \mathrm{PE} / \mathrm{g} \mathrm{DE})$, while its methanol extract held carotenoids content of $66.96 \pm 4.78 \mu \mathrm{g} \mathrm{g}^{-1} \mathrm{DE}$. Ethanol extract of $C$. mediterranea exhibited the best antioxidant activity with an $\mathrm{EC}_{50}$ of $58.3 \pm 1.16 \mu \mathrm{g} \mathrm{ml}^{-1}$. The antibacterial activity screening against MRSA and $E$. coli showed that ethanol extract of $C$. mediterranea towards a Methicillin resistant Staphyloccocus aureus $(20.33 \pm 0.28 \mathrm{~mm})$ and $E$. coli $(15.66 \pm 0.57 \mathrm{~mm})$ was more efficient with MICs about $80 \mathrm{mg} \mathrm{ml}^{-1}$ and $20 \mathrm{mg} \mathrm{ml}^{-1}$, respectively. Ethanol extract of $C$. mediterranea seems to have the highest potential for use in food industries.

Keywords: seaweeds, phlorotannins, carotenoids, antibacterial activity, antioxidant activity
\end{abstract}

Oxidative stress occurs when the production of reactive oxygen species (ROS) exceeds the limited capacity of the cellular antioxidant defence system. It is a condition that might occur in all aerobic organisms (O'SulLivan et al., 2011). It is implicated in several diseases such as hypertension, neurological disorders, diabetes, cancer, and inflammatory diseases. ROS are also involved in food damage as lipid oxidations, protein degradations, shelf life reduction, rancid flavours and odour production, all these damages may lead to food toxicity (BoIsvERT et al., 2015).

Food industry recognised food-borne diseases and food spoilage as main challenges, in addition to consumer concern regarding the incorporation of synthetic antimicrobials in food. The extensive use of conventional antibiotics leads to an emergence of resistant bacterial strains that can be found in food. Thus, safe new types of antimicrobials and antioxidants from natural sources are researched by food and pharmaceutical industries (Cox et al., 2010; Eom et al., 2012).

Algae occupy an important place in the marine environment with more than 1200 species belonging to all evolutionary levels, capable of producing substances which act in some cases as an element of protection against natural predators (CONDE et al., 2013), these substances are polysaccharides, lipids, or even phenolic compounds including phlorotannins found only in brown algae (PÉREz et al. 2016). Phlorotannins are polymers of phloroglucinol

* To whom correspondence should be addressed.

E-mail: badria_kera@yahoo.fr 
units (1, 3,5-trihydroxybenzene), they are therefore more effective than tannins derived from land plants (KoIVIKKo et al., 2005). The secondary metabolites of seaweeds are known to exhibit several activities, as anti-tumoural (NODA et al., 1990), antiviral (SoARES et al., 2012), antimicrobial (REICHELT \& BorowITZKA, 1984), and antioxidant activities (HAQ et al., 2019).

Because of the possible toxicity of synthetic antioxidants and the appearance of antimicrobial resistance, the search for new bioactive molecules has become a necessity. Thus, the aim of this work was to evaluate antioxidant activity of four different extracts (water, ethanol, methanol, and chloroform) of two brown algae Padina pavonica and Cystoseira mediterranea from the west coast of Bejaia (Northern Algeria). The antibacterial activity against two pathogenic strains: Methicillin resistant Staphyloccocus aureus (MRSA) and Escherichia coli was also investigated.

\section{Materials and methods}

\subsection{Plant material}

Two brown marine algae Padina pavonica and Cystoseira mediterranea were collected from the west coast of Bejaia (Algeria) in April 2019. The samples were washed with fresh water, and a last wash with distilled water was performed before drying at $40{ }^{\circ} \mathrm{C}$ in a ventilated oven. The dried algae were ground and sieved to obtain a powder of particle size below 63 $\mu \mathrm{m}$.

\subsection{Extraction of bioactive compounds}

Based on preliminary results, four solvents of different polarity were used, namely: water and ethanol as food grade solvents and methanol and chloroform were used because of their earlier good results. The extraction was carried out by maceration following the method of $\mathrm{CHO}$ and co-workers (2007), the dry extract was subsequently stored at $-80^{\circ} \mathrm{C}$ until use.

\subsection{Total phenolic content (TPC)}

The total phenols content of all extracts were measured using the Folin-Ciocalteu assay following the protocol of ŠKERGET and co-workers (2005). The different extracts were assayed at concentrations of $10 \mathrm{mg} \mathrm{ml}^{-1}$. The results were expressed in milligram equivalent of gallic acid per gram of dry extract (mg GAE/g).

\subsection{Phlorotannin content}

The determination of phlorotannins was carried out according to the protocol of STERN and co-workers (1996). The concentration of extracts used for this assay was $2 \mathrm{mg} \mathrm{ml}^{-1}$. Phlorotannins content was expressed as $\mathrm{mg}$ phloroglucinol equivalent per gram of dry extract (mg PGE/g).

\subsection{Carotenoid content}

The protocol of GiLBERT-López and co-workers (2017) was used to determine the total carotenoid content. The results were expressed in $\mathrm{mg}$ carotenoids per gram of dry extract $\left(\mathrm{mg} \mathrm{g}^{-1}\right)$. 


\subsection{Antioxidant activity}

The antioxidant activity of the extracts was evaluated by the DPPH method of BRANDWiLliams and co-workers (1995). Different concentrations were prepared for each extract (ranging from 0.3125 to $5.0 \mathrm{mg} \mathrm{ml}^{-1}$ ), to obtain the residual DPPH concentration until the achievement of the reaction. The obtained values were used to estimate the extract concentration necessary to accomplish a 50\% reduction of the initial DPPH concentration $\left(\mathrm{EC}_{50}\right)$. Measurements were done in triplicate.

\subsection{Antibacterial activity}

Two bacterial strains were used to assess the antibacterial activity. One Gram-positive bacterium: A Methicillin resistant Staphyloccocus aureus (MRSA) (LGA 251) and one Gram-negative: Escherichia coli (ST 131), supplied by the Laboratory of Applied Microbiology, University of Bejaia.

1.7.1. Screening of the antibacterial activity. The agar diffusion method followed the procedure described by FARID and co-workers (2009). The different extracts where sterilised by filtration under pressure using Millipore membranes $(0.45 \mu \mathrm{m})$ at a concentration of 50 $\mathrm{mg} \mathrm{ml}^{-1}$. The reconstitution solvents were used as negative controls.

1.7.2. Minimum inhibitory concentrations (MICs). The MIC is defined as the lowest concentration of extract that inhibits the growth of microorganisms after incubation. A broth microdilution method was used following the method of SANTOYO and co-workers (2009). Test strains were suspended in Mueller-Hinton broth to give a final density of $10^{7} \mathrm{CFU} \mathrm{ml}{ }^{-1}$. Different concentrations of the extracts ranging from 10 to $150 \mathrm{mg} \mathrm{ml}^{-1}$ were used. The 96-microwell plates were prepared by dispensing $165 \mathrm{ml}$ of culture broth, $5 \mathrm{ml}$ of the inoculum, and $30 \mathrm{ml}$ of the different extract dilutions into each well. The microplates were incubated at $37^{\circ} \mathrm{C}$ for $24 \mathrm{~h}$. Negative controls were prepared adding $30 \mathrm{ml}$ of the solvent to the culture broth containing $0.5 \%$ Tween 20 . Chloramphenicol was used as positive standard. After incubation, the MIC was determined by visual detection. The minimum inhibitory concentration is designated as the lowest concentration of the extract, where a lack of a white "pellet" is detected.

\subsection{Statistical analysis}

All assays were carried out in triplicate. Results were expressed as mean \pm standard deviation. Data were analysed using the analysis of variance test (ANOVA). Significant differences $(\mathrm{P}<0.05)$ between the averages were determined by the LSD test (Least Significant Difference) using STATISTICA 5.5 software. Correlation tests between phenolic compounds contents and antioxidant and antibacterial activities were carried out using the same software.

\section{Results and discussion}

\subsection{Total phenolic content}

Results depicted that $C$. mediterranea exhibited the highest levels of phenolic compounds with the water (37.1 $\pm 0.46 \mathrm{mg} \mathrm{GAE} / \mathrm{g})$ and methanol extracts $(23.66 \pm 0.24 \mathrm{mg} \mathrm{GAE} / \mathrm{g})$ (Table 1). Ethanol extract displayed the highest phenolic content in P. pavonica $(24.28 \pm 0.99 \mathrm{mg}$ 
GAE/g). Significant differences were observed between the extracts of the four solvents in each species $(\mathrm{P}<0.05)$ except ethanol and chloroform extracts of $C$. mediterranea and aqueous and methanol extracts of P. pavonica.

Table 1. Phenolic compound contents and antioxidant capacity of the studied marine algae

\begin{tabular}{llcccc}
\hline Marine algae & Solvent & $\begin{array}{c}\text { TPC } \\
(\mathrm{mg} \mathrm{GAE} / \mathrm{g} \mathrm{DE})\end{array}$ & $\begin{array}{c}\text { Phlorotannins } \\
(\mathrm{mg} \mathrm{PGE} / \mathrm{g} \mathrm{DE})\end{array}$ & $\begin{array}{c}\text { Carotenoids } \\
\left(\mu \mathrm{g} \mathrm{g}^{-1} \mathrm{DE}\right)\end{array}$ & $\begin{array}{c}\mathrm{DPPH} \\
\mathrm{EC}_{50}\left(\mu \mathrm{g} \mathrm{m} \mathrm{m}^{-1}\right)\end{array}$ \\
\hline $\begin{array}{l}\text { Cystoseira } \\
\text { mediterranea }\end{array}$ & Water & $37.09 \pm 0.46^{\mathrm{a}}$ & $0.41 \pm 0.09^{\mathrm{c}}$ & $60.57 \pm 5.57^{\mathrm{b}}$ & $546.01 \pm 20.07^{\mathrm{d}}$ \\
& Ethanol & $13.1 \pm 0.69^{\mathrm{f}}$ & $0.88 \pm 0.12^{\mathrm{b}}$ & $43.54 \pm 1.5^{\mathrm{c}}$ & $239.58 \pm 1.55^{\mathrm{b}}$ \\
& Methanol & $23.66 \pm 0.24^{\mathrm{c}}$ & $0.24 \pm 0.01^{\mathrm{d}}$ & $40.42 \pm 1.88^{\mathrm{c}}$ & $474.5 \pm 38.35^{\mathrm{c}}$ \\
& Chloroform & $14.62 \pm 1.72^{\mathrm{e}}$ & $0.27 \pm 0.07^{\mathrm{cd}}$ & $16.72 \pm 0.99^{\mathrm{d}}$ & $58.3 \pm 1.15^{\mathrm{a}}$ \\
& Water & $15.68 \pm 1.83^{\mathrm{d}}$ & $0.07 \pm 0.01^{\mathrm{e}}$ & $19.09 \pm 1.45^{\mathrm{d}}$ & $221.92 \pm 24.57^{\mathrm{b}}$ \\
& Ethanol & $24.28 \pm 0.99^{\mathrm{b}}$ & $1.18 \pm 0.018^{\mathrm{a}}$ & $21.46 \pm 1.34^{\mathrm{d}}$ & $637.96 \pm 16.06^{\mathrm{e}}$ \\
& Methanol & $16.52 \pm 0.37^{\mathrm{d}}$ & $0.34 \pm 0.05^{\mathrm{cd}}$ & $66.96 \pm 4.78^{\mathrm{a}}$ & $545 \pm 11.4^{\mathrm{d}}$ \\
& Chloroform & $6.63 \pm 0.37^{\mathrm{g}}$ & $0.32 \pm 0.03^{\mathrm{cd}}$ & $11.76 \pm 0.33^{\mathrm{e}}$ & $2764 \pm 45.8^{\mathrm{f}}$ \\
\hline
\end{tabular}

Each value represents a mean \pm standard deviation $(n=9)$.

Values bearing the same letters show no significant differences $(\mathrm{P}<0.05)$.

CALliste and co-workers (2001) reported that the polarity of the solvent plays a key role in the distribution of phenolic compounds between different solvents. The algae harvest was done in spring. ZHANG and THOMSEN (2019) showed that in addition to extrinsic (climatic) factors, genetic factors, degree of maturation of the plant, and storage time have strong influence on polyphenol content.

\subsection{Carotenoid content}

Statistical analysis showed significant differences between all analysed samples $(\mathrm{P}<0.05)$. The highest levels of carotenoids were recorded in the methanol extract of $P$. pavonica $\left(66.96 \pm 4.78 \mu \mathrm{g} \mathrm{g}^{-1}\right)$, followed by the aqueous extract of $C$. mediterranea $\left(60.57 \pm 5.57 \mu \mathrm{g} \mathrm{g}^{-1}\right)$. These results are in agreement with those of JACOBSEN and co-workers (2019). Carotenoids are lipophilic compounds, fragmentation to separate the water-soluble compounds from fatsoluble ones could be necessary to eliminate a large part of molecules, which could potentially give false positive results, such as polysaccharides.

\subsection{Phlorotannin content}

Significant difference $(\mathrm{P}<0.05)$ of phlorotannin content between ethanol extract and all other samples was found for both species. The highest phlorotannin contents were displayed by ethanol extracts of $P$. pavonica $(1.18 \pm 0.018 \mathrm{mg}$ PGE/g) and C. mediterranea $(0.88 \pm 0.12 \mathrm{mg}$ PGE/g), while the weakest was exhibited by aqueous extract of $P$. pavonica. Phlorotannins consist of polymers of phloroglucinol (1,3,5-trihydroxybenzene), they are a great class of marine secondary metabolites generally considered to act as chemical defence against herbivores; They also possess primary functions such as contributing to cell wall structure and reproduction (SINGH \& SidAna, 2013). The same researchers reported that low-depth 
samples of algae show higher concentrations of phlorotannins than samples harvested in deep waters. Knowing that, the two species, P. pavonica and C. mediterranea, were harvested at shallow depth.

\subsection{Antioxidant activity}

C. mediterranea extracts showed important activities compared to the extracts of P. pavonica, except for the aqueous extract. The ethanol extract of $C$. mediterranea showed a significant antioxidant activity with an $\mathrm{EC}_{50}$ of $58.3 \pm 1.15 \mu \mathrm{g} \mathrm{ml}^{-1}$ followed by its methanol extracts and aqueous extract of P. pavonica. We also noticed that active extracts with DPPH are also the ones containing more PC according to the Folin-Ciocalteu assay. A positive correlation $(\mathrm{r}=0.84)$ between the total phenolic content and the antioxidant activity for $C$. mediterranea was noticed, demonstrating the role of algal polyphenols as antioxidants. These results suggest that ethanol extract of $C$. mediterranea is a good alternative to replace chemical antioxidants in food as ethanol is an approved food grade solvent.

\subsection{Antibacterial activity}

2.5.1. Agar diffusion method. The diffusion method was used for preliminary screening to provide a general assessment of the antibacterial activity of the extracts. The diameters of the inhibition zones are presented in Table 2. The extracts tested exhibited an antibacterial activity with diameters ranging from 8 to $20.33 \mathrm{~mm}$. The largest inhibition zones were obtained for ethanol extract of $C$. mediterranea towards MRSA $(20.33 \mathrm{~mm})$ and $E$. coli $(15.66 \mathrm{~mm})$, this activity correlates with the phlorotannin contents. The lowest inhibition zones were obtained with the chloroform extracts of both algae. A slight activity was observed with ethanol and methanol extract of $P$. pavonica. A good correlation was established between the TPC of this alga and its activity towards E.coli $\mathrm{r}=0.76$ and MRSA $\mathrm{r}=0.93$. According to PÉREZ and co-workers (2016), different species of the genus Padina showed antibacterial activity against Staphylococcus aureus, Streptococcus pyogenes, and E. coli, and Cystoseira trinodis against $S$. aureus, Bacillus subtilis, E. coli, and Pseudomonas aeruginosa.

Table 2. Antibacterial activity of the studied marine algae

\begin{tabular}{|c|c|c|c|c|c|}
\hline \multirow[t]{2}{*}{ Marine algae } & \multirow[t]{2}{*}{ Solvent } & \multicolumn{2}{|c|}{ E. coli } & \multicolumn{2}{|c|}{ MRSA } \\
\hline & & $\begin{array}{l}\text { Diameters of } \\
\text { inhibition zones } \\
(\mathrm{mm})\end{array}$ & $\begin{array}{c}\text { MIC } \\
\left(\mathrm{mg} \mathrm{ml}^{-1}\right)\end{array}$ & $\begin{array}{c}\text { Diameters of } \\
\text { inhibition zones } \\
(\mathrm{mm})\end{array}$ & $\begin{array}{c}\mathrm{MIC} \\
\left(\mathrm{mg} \mathrm{ml}^{-1}\right)\end{array}$ \\
\hline \multirow{4}{*}{$\begin{array}{l}\text { Cystoseira } \\
\text { mediterranea }\end{array}$} & Water & $11.00 \pm 00.00^{\mathrm{bc}}$ & 100 & $9 \pm 00^{d}$ & 80 \\
\hline & Ethanol & $15.66 \pm 00.57^{\mathrm{a}}$ & 80 & $20.33 \pm 0.28^{\mathrm{a}}$ & 20 \\
\hline & Methanol & $10.5 \pm 0.3^{\mathrm{c}}$ & 100 & $14.33 \pm 0.15^{\mathrm{b}}$ & 40 \\
\hline & Chloroform & $9 \pm 00^{\mathrm{d}}$ & I & $8 \pm 00^{\mathrm{e}}$ & 1 \\
\hline \multirow[t]{4}{*}{ Padina pavonica } & Water & $11 \pm 0.26^{\mathrm{bc}}$ & 60 & $13 \pm 00^{\mathrm{c}}$ & 100 \\
\hline & Ethanol & $11.66 \pm 0.76^{\mathrm{b}}$ & 60 & $14.33 \pm 0.15^{\mathrm{b}}$ & 75 \\
\hline & Methanol & $8.66 \pm 0.76^{\mathrm{de}}$ & 40 & $13.33 \pm 0.57^{\mathrm{c}}$ & 100 \\
\hline & Chloroform & $8.13 \pm 0.23 \mathrm{e}$ & I & $9 \pm 00 \mathrm{~d}$ & I \\
\hline
\end{tabular}

MIC: Minimum inhibitory concentration

Each value represents a mean \pm standard deviation $(n=9)$.

Values bearing the same letters show no significant differences $(\mathrm{P}<0.05)$.

Acta Alimentaria 49, 2020 
2.5.2. Minimum inhibitory concentrations (MICs). Broth micro-dilution method is a quantitative assay used for the assessment of the minimum inhibitory concentration (MIC) of the studied seaweed extracts (Table 2). The lowest concentration that inhibited the bacterial growth was obtained for the ethanol extract of $C$. mediterranea against MRSA $\left(20 \mathrm{mg} \mathrm{ml}^{-1}\right)$ followed by methanol extracts of both algae $\left(40 \mathrm{mg} \mathrm{ml}^{-1}\right)$ toward MRSA and E. coli. The other extracts inhibited the bacterial growth at concentrations up to $100 \mathrm{mg} \mathrm{ml}^{-1}$. Previous research noticed maximal antimicrobial potential in spring, probably due to the dominance of some active compounds in this period. The chemical composition of marine algae, as well as their antimicrobial activities, varies with species, season, and region of harvest (CoNNAN et al., 2007; PÉREZ et al., 2016). Indeed, the efficiency of phlorotannins against MRSA has already been established, and a strong inhibition of microbial cell membrane integrity along with cell metabolism has been reported (Eom et al., 2012)

\section{Conclusions}

In this study, the ethanol extract of $C$. mediterranea exhibited the most effective antioxidant activity. A correlation between the total phenolic contents of $C$. mediterranea and the antioxidant activity was observed in DPPH assay, which agrees with the literature. Both algae species showed a good antibacterial activity, their MICs revealed that $C$. mediterranea was more active against MRSA, which was correlated with its phlorotannin content, as well as $P$. pavonica towards E. coli. Our findings, although preliminary and requiring applications in food systems, demonstrated the high potential of ethanol extract of $C$. mediterranea for use as a food conservative, knowing that ethanol is an approved food grade solvent.

\section{References}

Boisvert, C., Beaulieu, L., Bonnet, C. \& Pelletier, É. (2015): Assessment of the antioxidant and antibacterial activities of three species of edible seaweeds. J. Food Biochem., 39(4), 377-387.

Brand-Williams, W., Cuvelier, M.E. \& Berset, C. (1995): Use of a free radical method to evaluate antioxidant activity. LWT-Food Sci. Technol., 28(1), 25-30.

Calliste, C.-A., Trouillas, P., Allais, D.-P., Simon, A. \& Duroux, J.-L. (2001): Free radical scavenging activities measured by electron spin resonance spectroscopy and B16 cell antiproliferative behaviors of seven plants. $J$. Agr. Food Chem., 49, 3321-3327.

Cho, S., Kang, S., Cho, J., Kim, A., Park, S., ... \& Ahn, D.-H. (2007): The antioxidant properties of brown seaweed (Sargassum siliquastrum) extracts. J. Med. Food, 10(3), 479-485.

Conde, E., Balboa, E.M., Parada, M. \& Falqué, E. (2013): Algal proteins, peptides and amino acids. -in: Domínguez, H. (Ed.) Functional ingredients from algae for foods and nutraceuticals. Woodhead Publishing. pp. $135-180$.

Connan, S., Deslandes, E. \& Gall, E.A. (2007): Influence of day-night and tidal cycles on phenol content and antioxidant capacity in three temperate intertidal brown seaweeds. J. Exp. Mar. Biol. Ecol., 349(2), 359-369.

Cox, S., Abu-Ghannam, N. \& Gupta, S. (2010): An assessment of the antioxidant and antimicrobial activity of six species of edible Irish seaweeds. Int. Food Res. J., 17, 205-220.

Eom, S.-H., KIm, Y.-M. \& KIM, S.-K. (2012): Antimicrobial effect of phlorotannins from marine brown algae. Food Chem. Toxicol., 50, 3251-3255

FARID, Y., ETAHIRI, S. \& AssobHei, O. (2009): Activité antimicrobienne des algues marines de la lagune d'Oualidia (Maroc) : Criblage et optimisation de la période de la récolte. J. Appl. Biosci., 24, 1543-1552.

Gilbert-López, B., Barranco, A., Herrero, M., Cifuentes, A. \& Ibáñez, E. (2017): Development of new green processes for the recovery of bioactives from Phaeodactylum tricornutum. Food Res. Int., 99, 1056-1065. 
Haq, S.H., Al-Ruwaished, G., Al-Mutlaq, M.A., Naji, S.A., Al-Mogren, M., ... \& Al-Mussallam, A. (2019): Antioxidant, anticancer activity and phytochemical analysis of green algae, Chaetomorpha collected from the Arabian Gulf. Sci. Rep., 9(1), 1-7.

Jacobsen, C., Sørensen, A.-D.M., Holdt, S.L., Akoh, C.C. \& Hermund, D.B. (2019): Source, extraction, characterization, and applications of novel antioxidants from seaweed. Annu. Rev. Food Sci. T., 10, 541-568.

Koivikko, R., Loponen, J., Honkanen, T. \& Jormalainen, V. (2005): Contents of soluble, cell-wall-bound and exuded phlorotannins in the brown alga Fucus vesiculosus, with implications on their ecological functions. $J$. Chem. Ecol., 31(1), 195-212.

Noda, H., Amano, H., Arashima, K. \& Nisizawa, K. (1990): Antitumor activity of marine algae. Hydrobiologia, 204(1), 577-584.

O'Sullivan, A.M., O'Callaghan, Y.C., O'Grady, M.N., Queguineur, B., Hanniffy, D., ... \& O'Brien, N.M. (2011): In vitro and cellular antioxidant activities of seaweed extracts prepared from five brown seaweeds harvested in spring from the west coast of Ireland. Food Chem., 126, 1064-1070.

Pérez, M.J., FalquÉ, E. \& Domínguez, H. (2016): Antimicrobial action of compounds from marine seaweed. Mar. Drugs, 14(3), 52. 38 pages.

Reichelt, J.L. \& BorowitzKa, M.A. (1984): Antimicrobial activity from marine algae Results of a large-scale screening programme. Hydrobiologia, 116(1), 158-168.

Santoyo, S., Rodríguez-Meizoso, I., Cifuentes, A., Jaime, L., García-Blairsy Reina, G., ... \& Ibáñez, E. (2009): Green processes based on the extraction with pressurized fluids to obtain potent antimicrobials from Haematococcus pluvialis microalgae. LWT-Food Sci. Technol., 42, 1213-1218.

Singh, I.P. \& SidAna, J. (2013): 5-Phlorotannins. -in: Domínguez, H. (Ed.) Functional ingredients from algae for foods and nutraceuticals. Woodhead Publishing. pp. 181-204.

ŠKerget, M., KotniK, P., Hadolin, M., Hraš, A.R., Simonič, M. \& Knez, Ž. (2005): Phenols, proanthocyanidins, flavones and flavonols in some plant materials and their antioxidant activities. Food Chem., 89(2), 191-198.

Soares, A.R., Robaina, M.C.S., Mendes, G.S., Silva, T.S.L., Gestinari, L.M.S., ... \& Romanos, M.T.V. (2012): Antiviral activity of extracts from Brazilian seaweeds against herpes simplex virus. Rev. Bras. Farmacogn., 22(4), 714-723.

Stern, J.L., Hagerman, A.E., Steinberg, P.D. \& Mason, P.K. (1996): Phlorotannin-protein interactions. J. Chem. Ecol., 22(10), 1877-1899.

Zhang, X. \& Thomsen, M. (2019): Biomolecular composition and revenue explained by interactions between extrinsic factors and endogenous rhythms of Saccharina latissima. Mar. Drugs, 17(2), 107. 